by Rosa Maria Di Maggio ${ }^{*}$, Laurance J. Donnelly ${ }^{2}$, Khudooma Saeed Al Naimi ${ }^{3}$, Pier Matteo

Barone ${ }^{4}$, Fabio Augusto Da Silva Salvador ${ }^{5}$,Lorna Dawson 6 , Roger Dixon ${ }^{7}$, Rob Fitzpatrick ${ }^{8}$, Olga Gradusova 9 , Ekaterina Nesterina 9 , Marina Peleneva 9 , Olga Ushacova ${ }^{10}$, Carlos Martin Molina Gallego ${ }^{11}$, Duncan Pirrie ${ }^{12}$, Alastair Ruffell ${ }^{13}$, Jennifer McKinley ${ }^{13}$, Gullermo Sagripanti ${ }^{14}$, Diego Villalba ${ }^{14}$, Bill Schneck ${ }^{15}$, Ritsuko Sugita ${ }^{16}$, Grant Wach $^{17}$, Ricardo Silva ${ }^{17}$, and Shari Forbes ${ }^{18}$

\title{
Global developments in forensic geology
}

\author{
${ }^{1}$ Geoscienze Forensi Italia, Roma, Italia (Formerly Servizio Polizia Scientifica, Italia); Officer for Europe, International Union of Geological \\ Sciences, Initiative on Forensic Geology (IUGS-IFG); *Corresponding author, E-mail: rosamaria.dimaggio@gmail.com \\ ${ }^{2}$ International Union of Geological Sciences, Initiative on Forensic Geology (IUGS-IFG); Arup, Manchester, UK \\ ${ }^{3}$ Abu Dhabi Police, UAE \\ ${ }^{4}$ American Univrsity of Rome, Italy \\ ${ }^{5}$ Brazilian Federal Police, Braszilia, Brazil \\ ${ }^{6}$ The James Hutton Institute, Scotland \\ ${ }^{7}$ University or Pretoria, South Africa \\ ${ }^{8}$ CSIRO \& University of Adelaide, Australia \\ ${ }^{9}$ Russian Federal Centre of Forensic Science, Moscow, Russia \\ ${ }^{10}$ Federal Budget Institution Southern Regional Centre, Russia \\ ${ }^{11}$ Instituto Nacional de Medicina Legal y Ciencias Forense, Bogota, Colombia \\ ${ }^{12}$ Helford Geoscience LLP, Cornwall, UK \\ ${ }^{13}$ Queens University Belfast, Northern Ireland, UK \\ ${ }^{14}$ Departamento de Geologia, Universidad Nacional de Rio Cuarto, Córdoba, Argentina \\ ${ }^{15}$ Washington State Patrol Crime Lab, USA \\ ${ }^{16}$ National Research Institute of Police Science, Japan \\ ${ }^{17}$ Basin and Reservoir Lab, Dalhousie University, Halifax, Nova Scotia, Canada \\ ${ }^{18}$ University of Technology, Sydney, Australia
}

(Received: November 11, 2016; Revised accepted: March 4, 2017)

http://dx.doi.org/10.18814/epiiugs/2017/v40i2/017014

Forensic geology has developed in each country dependent on the history, political and social setting, anthropological influences and geology. The aim of this section is to provide a global overview of forensic geology, including the history, developments and future challenges in Africa, Asia, Australia, Canada, Europe, Middle East, Latin America and the Caribbean, Russia and Commonwealth Independent States (CIS), and USA.

\footnotetext{
Africa

South Africa has been leading the way in forensic geology in Africa, although there has also been some work in countries such as Botswana. In contrast to many other regions around the World, in Africa the main application of forensic geology has been linked to the regions extensive mining industry. In the past few years the major development in forensic geology in South Africa has been the implementation of accurate characterization of ores and intermediate products of the precious metal industry. The illicit cross-border trade in these high value, low volume materials has made them a sought-after commodity, especially in less-developed nations and isolated areas,
}

and has established them as global currencies. The ultimate beneficiaries are often well-organised syndicates also involved in a variety of other illegal activities, such as drug and firearm trafficking, with wide-reaching contacts. Presenting a global threat, this can best be monitored and opposed on an international level.

South Africa has introduced legislative measures requiring samples of all imported and South African produced unrefined precious metals to be sent to the Forensic Science Laboratory (FSL) of the South African Police Services, which maintains a database to aid the recognition of illegal precious metals and to ideally trace them back to their original source. The ultimate aim is not only to return such metals to the mines from which they were stolen, but also to investigate syndicate operations and the movement of precious metal containing materials to refineries all over the world (Dixon et al., 2007).

The theft of platinum group metal bearing materials from smelters and refineries is a world-wide problem, with stolen materials being refined in countries far from source and usually without local sources of raw materials. In southern Africa, a large proportion of the materials at risk are converter mattes from the smelters, which are smuggled to refineries, mainly in Europe, and the onus is on the producer to prove origin. In order to combat this illicit trade, an internationally accepted method for fingerprinting of recovered mine and plant prod- 
ucts, with collaboration between South African (FSL, now University of Pretoria, and Anglo Research) and Russian producers (ENFSI, 2008), has been implemented, both in Russia (Perelygin et al., 2008) and in South Africa, in order to return recovered material to the legal owners, and enabling successful prosecution in international courts.

South Africa is a hub for gold trading in Africa, with many legal mining companies bringing gold in to be refined. It is also a mecca for illicit gold traders. For example, it is reported that around $70 \%$ of the gold currently being mined in the Democratic Republic of Congo (DRC) has been exported illegally (White, 2005), reaching up to $95 \%$ in the eastern DRC. A major project of the Forensic Science Laboratory, has been the identification of elemental and isotopic source markers of gold, mainly to determine its origin within Africa. This expertise has been successful not only in South Africa (Roberts et al., 2016), but also in criminal cases in South America and elsewhere.

These programs have now been elevated to higher international status, with the United Nations Interregional Crime and Justice Research Institute (UNICRI) making the prevention and detection of illicit trafficking in precious metals one of its priorities.

In addition to metal products, there has also been an attempt to develop a fingerprinting method for characterising diamonds, which are illicitly mined in a number of countries in Africa, but the research carried out in South Africa has shown that this is very difficult to do (Coney et al., 2012).

There have been some publications in the international literature about the application of forensic geology in other parts of Africa, mainly dealing with the fingerprinting of gold and other minerals from the Congo and Great Lakes region, but these initiatives have originated in other European countries, and not in the countries from which the material is being illicitly taken from.

\section{Asia}

Modern forensic sciences in Asia commenced in the last quarter of the $19^{\text {th }}$ Century with varying speed of progress among different scientific disciplines. If there is an official network addressed to forensic geology, it is within the Asian Forensic Sciences Network (AFSN). This founded in 2009 with the purpose to provide a forum for all the forensic science institutes in Asia, to discuss issues relating to forensic services, work towards enhancing the quality of forensic services in member countries and establish links with other regional networks in the global forensic community. As part of this network, and through the IUGS-IFG activities, forensic geology will play an important role in helping to share scientific information and techniques, facilitating technical cooperation among Asian countries and setting guidelines regarding operational procedures, quality management, or accreditation. Furthermore, it is noteworthy that the book "Evidence from the Earth", written by the American forensic geologist Raymond Murray, has been now translated into Chinese.

\section{China}

Since 2007, forensic geology has received much attention in China. Some scientific research has been done to improve the ability to examine soil evidence. The elemental analysis of soil by XRF and ICP-
MS, mineral identification by XRD are now applied in case work. This is also supported by the analysis of pollen. Forensic scientists from the Institute of Forensic Science, Ministry of Public Security, are applying for funds from the Chinese Government to further develop forensic geology in China. Systematic forensic geology methods will support other forensic investigations that includes; chemical analysis, pollen examination, plant species identification by DNA barcoding method, microbiome investigation and isotope ratio technique will be carried out in soil identification.

During last thirty years, trace evidence, such as paints, glass and gun-shot residue has drawn much attention, especially in cases without DNA or fingerprint evidence. Soil samples related to crimes have been used occasionally in case work.

In China, soil evidence is examined in the Trace Evidence Division's at county and national forensic laboratories. In most cases only a comparison between soils samples have been made. To date, soil analysis has not been used to provenance a geographical location.

To help develop forensic geology in China, in 2014, the Institute of Forensic Science, Ministry of Public Security, began to collaborate with IUGS-IFG. This Institute formally became part of IUGS-IFG in 2016, following the forensic geology session held at the $35^{\text {th }}$ International Geological Congress in Cape Town, South Africa.

\section{Japan}

The importance of trace evidence, including geological matters, is increasing in Japan, with the introduction of the Citizen Judge System in 2009 , and changes in the circumstances of crime investigation and the judiciary system. Forensic geology in Japan has developed to examine soil and rocks as trace evidence related to crimes. Research and actual case work is mainly done by the police along with the help of academic laboratories and museums.

The importance of soil examination in crime investigation was recognised after the Second World War. A report on forensic soil examination was based on the procedures of the Association of Official Agricultural Chemists (renamed the Association of Official Analytical Chemists after 1965 (AOAC)). This was provided by the members of the Scientific Crime Detection Laboratory of National Rural Police Headquarters, a precursor institute of the National Research Institute of Police Science, Japan, as early as 1950. In this report, the need to develop a systematic procedure utilizing the observation of physical properties (e.g., colour and shape, as well as chemical analysis) was pointed out. The study of soil as trace evidence has been steadily continued by researchers in the national and prefectural police laboratories.

The systematic procedure for soil examination in Japan is based on physical and mineralogical examinations. Parts of the procedure are based on the results of studies of clay mineral examination by X-ray diffraction (Marumo et al., 1988) and on colour comparison for screening Sugita and Marumo 1996). It also includes grain size analysis, and microscopic observation of sand grains.

The term 'forensic geology' appeared in the announcement of the $2^{\text {nd }}$ Symposium on Geo-environments and Geotechnics in 1992. Since then, the committee of the symposiums has included forensic geology as one of the topics of interest for over 20 years (see The Japanese Society of Geo-Pollution Science, Medical Geology and Urban Geology 
web site). Most of the results of studies on forensic geology are presented at the symposia and at annual meetings of the Japanese Association of Forensic Science and Technology. However, these are not widely distributed as the abstracts and proceeding papers are written in Japanese. It will be the next challenge to Japanese researchers to contribute more fully to the international community.

\section{Australia}

The aim of forensic geology and soil trace analysis is to associate soil, rock or mineral samples taken from an item, such as shoes, clothing, shovel or vehicle with a specific location (Fitzpatrick, 2013a). Soil materials are powerful, perhaps ideal, pieces of contact trace evidence helpful in criminal investigations (Fitzpatrick, 2013b). The Centre for Australian Forensic Soil Science (CAFSS) was formed in 2003 at the request of the Australian forensic community following the success in assisting police solve a complex double murder case (Fitzpatrick and Raven 2012) to: (i) conduct specialized forensic science case work for Australian (State, Territory and Federal) and international police forces and related forensic science agencies and (ii) develop new criminal and environmental forensic techniques for soils, sediments and geological materials (e.g., advanced X-ray diffraction, spectroscopic, isotopic metagenomics, and biological methods).

CAFSS is the first formal worldwide network of soil and forensic scientists with critical expertise in soil forensics to support criminal and environmental pollution investigations. CAFSS is located in CSIRO Land and Water and is funded mostly by external incomes acquired from forensic geology and soil case investigations and court hearings. CAFSS staff members are regularly subpoenaed to testify in court. To meet these responsibilities CAFSS have developed Guidelines for Conducting Criminal and Environmental Soil Forensic Investigations (Fitzpatrick and Raven, 2016). The guidelines provide a systematic approach and use of appropriate standard methods for sampling, characterizing and examining soils for forensic comparisons. They also assist CAFSS in its mission by ensuring efficiency and accountability in the proper handling, storage and tracking of soil evidence, which is essential to evidence collection and ultimately prosecution.

So far, CAFSS has helped investigate over 170 serious criminalistic cases such as homicide, rape, kidnapping and counter-terrorism. A wide range of natural soil types (sandy coastal dunes, sandy swamps and clayey colluvium) and human-made soil types (comprising road, brick and bone fragment materials) across Australia have been used by CAFSS in these forensic investigations to associate materials taken from questioned items with a specific control location or the crime scene. CAFSS staff are now also using advanced automated techniques, which can acquire information from smaller samples to make soil forensics an increasingly popular tool in criminal investigations.

To illustrate the power of geological and soil trace analyses in criminal investigations it has been beneficial for CAFSS to share successful case examples to demonstrate the potential value of this somewhat underutilized forensic tool (see Fitzpatrick, 2008, 2013a, b; Fitzpatrick et al., 2009). When examining soil evidence, CAFSS has used a range of stages involving screening soil tests that help provide pieces of a puzzle and then more detailed tests that provide definitive answers. For example, when comparing geological and soil materials, especially if the questioned samples are very small sub-millimetre particles (less than $0.5 \mathrm{~mm}$ in size, and weighing less than a milligram) and if they comprise polycrystalline minerals, (e.g., cristobalite and mullite), such as in small brick or particles that have burnt to the earth from space. While CAFSS found traditional XRD techniques were adequate for determining the main soil/geological components, synchrotron XRD with high X-ray intensity was found to provide far greater sensitivity and resolution (Raven et al., 2011). For example, in one murder case the CAFSS team spent two years successfully linking minute brick particles in a murder victim's bra and hair to a collection of old brick pavers in the front yard of the victim's home - even to one specific type of brick (Raven et al., 2011).

The core business of CAFSS has been to provide a focus for applied research and development in the field of soil technology and forensic science by: (i) promoting science excellence and co-operation with stakeholders by conducting research, training and communicating results and analysis techniques to forensic scientists in Australia and internationally. To this end CAFSS conceived, developed and organized the "First International Workshop on Criminal and Environmental Soil Forensics", which followed the " $18^{\text {th }}$ International Symposium on the Forensic Sciences: Classroom to Courtroom" in April 2006.

The strength of forensic geological and soil evidence is becoming increasingly well accepted in Australia. In fact, five cases in Australia have been solved without forensic work actually being carried out. Detectives have simply told suspects or their legal teams that soil samples have been or will be collected for investigation and comparison by forensic soil scientists leading to a confession.

With regards to search investigations: The Australian Federal Police (AFP) have developed a unit to conduct ground searches to locate burials, which may include for example; homicide graves, mass genocide graves, weapons, firearms, drugs or items of value that have been buried beneath or concealed on the ground surface as part of a criminal act. The geophysical equipment available includes: ground penetrating radar, ferrous and non-ferrous metal detectors and electromagnetic sensors (EM38). However, an understating of the undisturbed (pre-burial) and disturbed (post-burial) geology and the target (body and associated objects) properties are crucial before the correct search strategy and choice of the above mentioned instrumentation may be decided, and the optimum method of deployment identified (see Donnelly and Harrison, 2013). These techniques include geophysics, geochemistry, satellite imagery, air photo interpretation and invasive methods (such as auguring, drilling, trial pitting and trenching). The AFP with other agencies have also conducted workshops covering the design, management and implementation of ground searches using geophysical equipment. An excavation difficulty map (colloquially called 'diggability' map) for Australia has been developed by Fitzpatrick (2015a) using the colour coded RAG prioritisation system in searches for criminal burials outlined by Donnelly and Harrison (2013). In 2012, IUGS-IFG in conjunction with the Australian Federal Police designed and delivered search training in Brisbane, as part of the IUGS $34^{\text {th }}$ IGC.

The Australian Facility for Taphonomic Experimental Research (AFTER) facility examines changes in biological profiles of soils associated with buried human remains in an Australian context and to utilise these changes to detect clandestine burials and estimate post mortem interval (PMI) of recovered remains. Dramatic biological changes during decomposition result in a range of biotic signals that have been 
used to locate hidden burials and to estimate PMI (e.g., Forbes et al., 2005; Benninger et al., 2008). This facility is the first, and only, of its kind in Australia and the southern hemisphere, and draws together a collaborative team of experts in forensic biology, chemistry and entomology, as well as archaeological science and palaeontology. Observed changes in inorganic (e.g., isotopes) and biological (DNA) signals during decomposition is being correlated with results from other forensic taphonomic disciplines to provide the most comprehensive information available to police and forensic services regarding the decomposition processes of human remains in their local environment. IUGSIFG has provided advice on geology, geophysics and geochemistry. It is proposed the results of leachate plume experiments conducted in the UK could be repeated at AFTER (Donnelly et al., 2016). It is expected the results will inform open area search strategies to locate unmarked homicide graves, missing person's remains and victims of genocide or mass disasters.

The recent development of advanced high-resolution DNA profiling of soils for forensic investigations and DNA sequencing technologies provides the potential to identify individual species or taxa (e.g., bacteria, plants, animals, and fungi) present in a soil sample, which will permit improved discrimination between soil samples. Young et al. $(2015,2016)$ recently examined and demonstrated the practical application of the use of DNA metabarcoding (PCR amplification of DNA mixtures using universal primers) combined with high-throughput sequencing (HTS) technology to distinguish soils from different locations in a forensic context based on the soil biota detected. However, before this approach can be employed as an additional tool in actual forensic soil science cases, additional studies are required to assess and quantify the vast "soil community" variation in different locations and habitats, and especially in soils that are subjected to seasonal variations (e.g., wetting and drying of acid sulfate soils).

Murray et al. (2015) have recently reported on the development of new image processing software to better interpret a series of soil transference experiments using anthropogenic and natural soil transfer to bra-cups and straps caused by dragging. Such soil transference research had applications to a homicide case. These workers have shown that soil type, clay mineralogy and soil moisture were the greatest influencing factors required to explain eight categories of soil transference patterns that they observed (both naked eye and measured properties).

In a recent homicide case, Fitzpatrick (2015b) conducted a series of laboratory transference shaking experiments with a clean strip of pyjama top fabric and using scanning electron microscopy (SEM) observed that the mineral particles were dominantly located on the surface of pyjama fabric. However, in the heavily stained seams of the questioned pyjama top the mineral particles were observed by SEM to be mostly deeply impregnated in gaps between the fibres of the fabric, which likely originated under water with some force being applied on the pyjama top.

\section{Canada}

The first session on forensic geology in Canada was held in May 2012, at the Geological and Mineralogical Association (GAC-MAC) annual meeting, in St. John's, Newfoundland. This included a series of knowledge transfer presentations on the history of forensic geology, geological trace evidence, water and land searches for burials.

Also in Newfoundland, the Royal Newfoundland Constabulary requested assistance in locating a firearm believed to be disposed of in a lake. This included the innovative applications ground penetrating radar from the bottom of a boat. The ground penetrating radar and high resolution antennae remained stationary in the boat as the boat completed a tight grid across the water.

Forensic geologists were also consulted on a criminal investigation in Nova Scotia. They were asked to advise on potential mineral material in catalogued evidence in police custody. This soil was sampled and XRD (X-ray diffraction) mineralogical analyses was completed in Europe. Identification of pollen contained in the soil samples was also undertaken. A review of the literature, maps and reports of soil and superficial geology surveys were also undertaken in an area where the evidence was thought to have originated.

There has been several other enquiries for using ground penetrating radar for archaeological projects ranging from investigating potential burial grounds of the Mi'kmaq indigenous people of Nova Scotia, historic graveyards and buried pirate treasure.

During 2008-2012, the Ontario Provincial Police (OPP) UCRT unit, particularly the Urban Search and Rescue (USAR) team that utilised ground penetrating radar and cadaver-detection dogs in the search for human remains. During this time, several dozen searches were carried out at the request of local, regional, provincial and federal police. Successful recoveries included a victim buried under concrete in a basement, child remains buried in a shallow grave on a reserve, and the excavation of the well-preserved remains of an OPP general purpose dog buried 36 years prior at his location of employment.

In 2016, two IUGS-IFG committee members were invited to attend an event organized by the Forensic Archaeology Special Interest Group and the Chartered Institute for Archaeologists (CIfA), in Bradford, UK. A forensic case study was delivered by a professor and defense lawyer involved to the Pickton Farm multiple murder case, in British Columbia.

Future forensic geology workshops are proposed in Vancouver and Halifax with scientists and investigative units from the various levels of civilian and military police forces. Field cases for the workshop include identifying buried human remains in a grave site thought to contain two children, a young women and older gentleman believed to be unrelated. Another case will be identifying the size of a pioneer gravesite and the number of people buried in the area.

\section{Europe}

\section{Italy}

In Italy, forensic geology became firmly established in the early 1980s for the investigation of kidnapping. For example, the presence of soil on motor vehicles examined by the police provided crucial information on the routes followed by the abductors and on the hiding places frequented by them. In 1978, forensic geologists in Italy were involved with the analysis of sediments found in the pocket of the murdered Italian Prime Minster, Aldo Moro.

The Soil Laboratory of the Italian State Police Forensic Science 
Department has established a soils analysis procedure, which produced effective and successful results. Nowadays, this analytical process is still used by forensic geologists aided by advanced technological instruments, and it is integrated with further tests able to yield more detailed information.

Over the last ten years, Forensic Laboratories have improved their performance thanks to the introduction of new scientific techniques providing further useful support to judicial investigations. In addition, forensic geology has received much attention from the media and academia. Some Universities have introduced courses on forensic geology with the aim of improving the professionalism of geologists, working as advisors and expert witnesses in criminal, civil, and environmental cases. Because of this, forensic geology plays a role that is becoming increasingly important. Forensic geologists, together with the forensic geoscience laboratories require accreditation to $\mathrm{ISO} /$ IEC17025 quality control standard and ISO9001 quality management system, which is stipulated by the Courts of Law, the investigators, and the defence.

The range of forensic geology applications in Italy includes; the analysis of soil traces and geological materials as evidence in crimes (such as homicides, kidnappings, etc.). Geophysical and geotechnical analysis is used in the search for burials, the investigation of environmental crimes, and in the investigation of landslides and subsidence due to criminal human intervention or interference.

The most recent application of forensic geology are focused on environmental crimes, which are widespread in Italy. Different kinds of "geo-crimes" include environmental or mafia related. In particular, environmental crime investigations apply the geomorphological analysis of aerial photographs and satellite imagery, Lidar, GIS, etc. In addition, in situ surveying is undertaken to support geophysical surveys using GPR, metal detector, resistivity and seismic reflection, and for the collection of geological and geochemical material as evidence.

The present and future challenge in Italy is how to bring together the different skills within forensic geology to ensure that data and information of value to the police investigation is effectively collected, managed and communicated so it can be presented as evidence. In Italy, the judge is "peritus peritorum" (expert of experts) in the court. This means that the judge is responsible for evaluating the reliability of any technical-scientific resources used in the process, hence a correct geological analysis at the crime scene is essential. Every geologist involved in a forensic investigation must be thoroughly prepared and understand possible procedures to be adopted because it is of primary importance that the optimal selection of scientific techniques is used in the recovery of evidence and its contextualization in the case being investigated (Di Maggio et al., 2013).

\section{Irish Republic}

Two main areas of forensic geology have been used in the Irish Republic. The first is in the area of ground searches, which are carried out by the Irish Police Force, the An Garda Siochana, for buried objects and also by the Independent Commission for the Location and Recovery of Human Remains (ICLVR) for buried victims of the period known as 'The Troubles' (1969-1998). An example of the work of the An Garda Siochana is the work conducted in conjunction with UK police and scientists on several missing persons (mainly young women) in the Wicklow Mountains, south of Dublin through the 1980s and 1990s. The ICLVR are a very successful group, set up by the governments of the UK and Ireland as part of the Good Friday Agreement that marked the end of The Troubles. Of the 16 missing people thought to have been abducted by paramilitary organisations, the ICLVR have recovered 9.

The second area of forensic geology used in Ireland concerns trace evidence, most notably when sand, paint and explosives residues were used by James O. Donovan of the An Garda Siochana Technical Bureau (Phoenix Park, Dublin) in the investigation into the murder of Lord Mountbatten offshore of County Sligo in 1979. The case brought against IRA volunteer Thomas McMahon was successful. Previous to this case, soil and sediment had only occasionally been used anywhere in the world, making Donovan's work pioneering. Geological trace evidence continues to be used by the Irish Police, most especially in gangland murders in Dublin and Limerick.

\section{United Kingdom}

Forensic geology provision in the United Kingdom (UK) is split into two main areas: intelligence gathering and evidence evaluation. Forensic geoscience covers the use of geological materials including soil in the provision of assistance in search operations, crime reconstruction and in the provision of trace evidence. Forensic geology came to prominence in the UK with a presentation on Forensic Geology and The Moors Murders, by L. Donnelly, to the House of Commons (UK Parliament) in 2002 (Donnelly, 2002). This he followed by the establishment of the Geological Society of London, Forensic Geoscience Group (FGG) in 2006 and IUGS-IFG in 2011. A geological trace evidence by a conference organised by K. Pye and D. Croft at the Geological Society of London (2003), followed by an edited book (Pye and Croft, 2004). Since then several key conferences have been hosted in the UK (Donnelly, 2008; Ritz et al., 2009; Pirrie et al., 2013).

In the UK, forensic geoscience is used predominantly in cases of serious crime such as murder, rape and in ground searches associated with organized crime and counter terrorism. Different aspects of forensic geoscience have been applied, depending on the case in question. For example, microfossil analysis was used in the R. v. Ian Huntley double murder case where the geological evidence was used to show that Ian Huntley had driven his car on the remote track where the bodies of his child victims Holly Wells and Jessica Chapman were found in 2002. More recently, a complementary approach using both inorganic and organic soil analysis was used in the search, recovery and also trace evidence provision in the murder of Pamela Jackson (R. v. Adrian Muir, 2013) where soil on the gloves belonging to the suspect was used to identify the body deposition site. In the murder of Rebecca Godden (R. v. Christopher Halliwell) soil recovered from tools were virtually indistinguishable from soil found at the grave site. In Scotland, in the investigation of the Worlds End murders and associated trial in 2014 (HMA v. Angus Sinclair) soil samples on the feet of one of the victims were shown to contain wheat grains and characteristics of the grass verge and the wheat soil where one of the victims, Helen Scott was found in 1977. Forensic geology has also been used in investigations in Northern Ireland, from the search for a murder victim (R. v. Trevor Hamilton), through the sampling of crime scenes (a body deposition site; R. v. Niall Porter) and the evaluation of 
soil trace evidence (R. vs. William Courtney, R. v. William Benson Young, and R. v. Henryck Gorski).

Geoscientists have assisted many police forces in crime reconstruction and in the search for persons or objects. One example is the successful location of a grave in the Pennines where the victim's body had previously lain undiscovered for at least 10 years. The geomorphological analysis of air photos also assisted with the finding of a grave in the north of England. Furthermore, geoscientists have assisted the police with evidential searches across the UK to locate buried items associated with serious crime or to prove the absence of a buried item. UK geoscientists have also provided formal and informal advice, training and operational support for law enforcement led searches throughout Europe, Asia, Africa, Australia, Canada, USA and Latin America. At the time of writing, forensic geoscientists are assisting the police with a few long term search operations such as the search for Moira Anderson with Police Scotland, for Arlene Atkinson with PSNI, the last remaining victim of the 'Moors Murders' in northern England and other MiSPER (Missing Persons) cases.

The majority of intelligence work is carried out directly for police forces and that is predominantly in assisting with ground search operations for missing people, unmarked homicide graves and for buried or concealed objects. The other area is in the analysis of natural soil/ superficial deposits in addition to artificial products derived from geological materials (e.g., glass, bricks, and tiles). Such analysis is used in the provision of evidence in court or in determining the geographical provenance of a questioned sample found on an item of interest associated with a crime. Geographical Information Science (GIS) is now routinely used in the UK to integrate and analyse different types of geocoded data with information from databases useful to forensic investigations. Working with the law enforcement agencies, the impact has been a more informed and integrated approach which has enabled a higher degree of quality assurance and a prioritising of potential search area. Forensic geoscience is a niche discipline, not provided inhouse within the larger forensic service providers, but usually subcontracted to individual experts with relevant experience and qualifications.

Intelligence work is generally carried out directly for the police forces. In Scotland, there is one police force, Police Scotland; in England there are 43 individual police forces; in Wales there are 4 police forces and in Northern Ireland there is the Police Service of Northern Ireland (PSNI). There are the special police forces that geoscientists also work with, such as the British Transport Police, the Civil Nuclear Constabulary and the Ministry of Defence Police. The environment agencies of the above areas of the UK also investigate specific crimes: in Northern Ireland the Northern Ireland Environment Agency Environmental Crime Unit have power of arrest, as do officers of the Royal Society for the Prevention of Cruelty to Animals and Birds. The Scottish Environment Protection Agency (SEPA) in Scotland and the Environment Agency (EA) in England and Wales fulfill this role. The UK military also work with forensic geologists, mainly through the various divisions of the Royal Engineers, but also in remote sensing for the Royal Air Force and for searches of water via the Royal Navy.

The UK is divided into several legal entities; these are the prosecuting authorities all operating under the adversarial legal system. England and Wales has the Crown Prosecution Service, Northern Ireland has the Public Prosecution Service and Scotland has the Crown Office and the Procurator Fiscal Services. As criminal cases are held in front of a jury in the UK, experts must be able to explain and communicate their science to legal experts and the general public (juries). In the UK, expert witnesses may also be appointed by defence counsel to challenge the expert opinions provided on behalf of the prosecution. Expert work carried out for the court is commissioned by the prosecution or defence or in some cases by the Criminal Cases Review Commission (CCRC); the role of the expert is to assist the court in understanding the evidence that they present.

When providing evidence it is important that authoritative guidance, protocols and approved standards are adhered to. Many forensic methods are accredited by United Kingdom Accreditation Service (UKAS) to the international laboratory ISO17025 quality control standard. This accreditation ensures that laboratories follow standard procedures and encourage the delivery of precise, accurate data. All other methods followed in forensic geoscience laboratories follow similar quality control procedures and are, in general, covered by ISO9001. Laboratories carrying out the case investigations are encouraged to have UKAS accreditation, to help ensure that a minimum acceptable and regulated standard is met. Currently, there is no approved standard for conducting ground searches, although some general guidance does exist in publications. The Forensic Science Regulator (FSR) UK, works with the UK Home Office and ensures that the provision of forensic science services across the criminal justice system is subject to an appropriate regime of scientific quality standards. The FSR also collaborates with the authorities in Scotland and Northern Ireland who have expressed their willingness to be partners in the setting of quality standards which will be adopted within their justice systems and are also represented on some of the working groups.

Practicing forensic geoscientists in the UK may become a Chartered Scientist, or register through their own professional societies (e.g., Chartered Geologist) or through membership of their professional organizations (e.g., the Geological Society of London or the European Federal of Geologists or the British Society of Soil Science). In addition, individual scientists have the option to register with the National Crime Agency (NCA) if they are invited to do so by the police.

Forensic geoscience provision in the United Kingdom delivers to aspects of intelligence, investigation, trace evidence and expert witness provision. Standards are continually improving and networks of experts such as the IUGS-IFG and ENFSI-ASPT enable good collaboration and shared good practice: offering complementary skills of great value in assisting police, forensic and legal practitioners across the UK and abroad.

\section{Middle East}

\section{United Arab Emirates}

The Abu Dhabi Police General Directorate has initiated a project focusing on forensic geoscience in order to test its application for forensic investigations in the UAE, such as the viability of using Ground Penetrating Radar (GPR). The Abu Dhabi Police has also collaborated with the International Union of Geological Sciences (IUGS) Initiative on Forensic Geology (IFG) and its officers serve on the 
IUGS-IFG committee to gain more support and cooperation in the field of forensic geology. As part of the Initiative on Forensic Geology, training in using new ground and water search equipment was presented to the forensic department under Abu Dhabi Police, Navy and Coast Guard in 2013. The UAE search team has used new equipment to train in underwater search, including the use of the Shark Navigator dual frequency sonar system.

An important part in the search for buried homicide victims includes the understanding of the geology of the UAE, as well as the mapping of soil and geological units. This helps the geologist and archaeologist in deciding what equipment to use and during searches. There is a resource which can be accessed on the internet, which provides a map outline of the geological variability within the UAE. In addition, the Abu Dhabi Police has opened a Geographical Information System Centre for Security (GISCS). This center can be used in conjunction with soil maps to help gather intelligence regarding the location of a clandestine grave.

In the UAE, forensic geology is also applied in the investigation of various crimes such as the "box-of-rocks" online scam (Arabian
Business, 2016) and fake gold cases. In 2004, the Abu Dhabi Police GHQ and the Environment Agency-Abu Dhabi (EAAD) signed a Memorandum of Understanding (MoU), on exchanging benefits of "the FOOTPRINT soil types" and "the Forensic Evidence laboratory", as well as to enhance mutual cooperation between them.

The $2^{\text {nd }}$ and the $3^{\text {rd }}$ International Conferences on Engineering Geophysics were held in 2013 and 2015 at Al Ain, UAE. These included sessions on forensic geology. Local police force officers attended both conferences (Donnelly, 2013; Donnelly and Harrison, 2015).

In 2016, the United Arab Emirates University (UAEU) signed a memorandum of understanding (MOU) with Abu Dhabi Police GHQ in the field of training and studies related to the Forensic Geology Science identifying crime scenes by using geophysical and geological scientific methods applied to criminal investigations (UAEU, 2016).

Recently, the Abu Dhabi Police arrested a soil expert for taking a Dh15,000 bribe: a 63 -year-old engineer was accused of taking a bribe to finalise a soil clearance transaction at a government laboratory in Abu Dhabi.
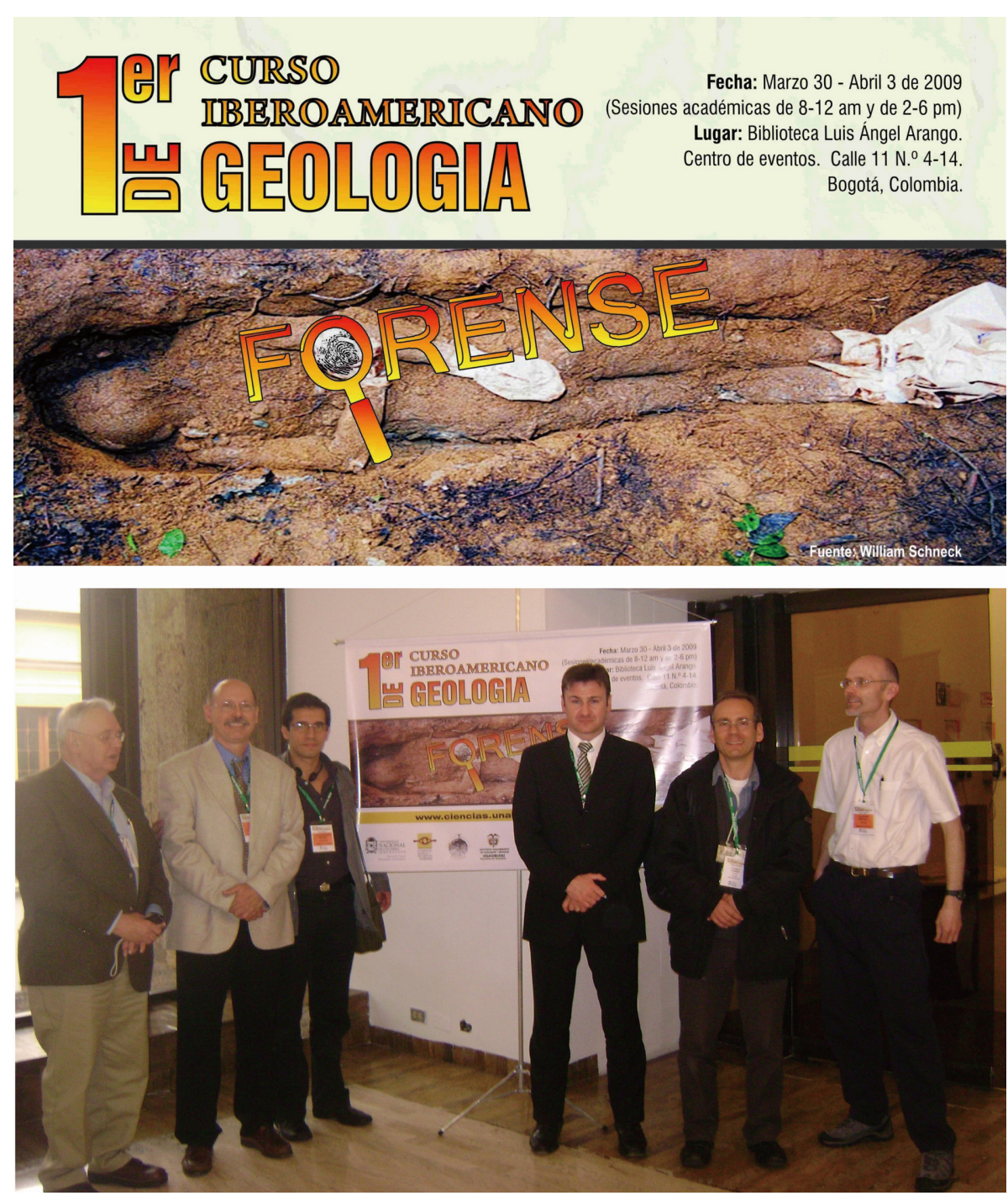

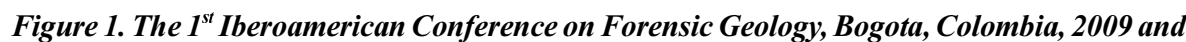
members of what was to become IUGS-IFG (Photos: William Schneck and Laurance Donnelly).

\section{Latin America and the Caribbean}

Since the later part of the $20^{\text {th }}$ Century, there has been advancements in forensic geology in some countries of Latin America. In 2009, the " ${ }^{\text {st }}$ Iberoamerican Course on Forensic Geology" was held in Bogotá, Colombia. This was organized with support of the National University of Colombia and the federal police and by international experts in forensic geology, who later became members of the IUGS-IFG committee. This lay the foundation for the increasingly specialized development of forensic geology throughout Latin America (Fig. 1). In 2010, the IUGS-GEM Forensic Geology Working Group met in Uruguay and training on forensic geology was held in Mexico during the same year. In 2013, the " 2 nd Iberoamerican Course on Forensic Geology" was held in Brasilia, Brazil. IUGS-IFG took part in this event and provided training for the Brazilian Federal Police. This was followed by advanced forensic geology training provided by IUGS-IFG in 2016, and further courses are planned in 2017. The $3^{\text {rd }}$ Iberoamerican Course on Forensic Geology is scheduled to take place in Cordoba, Argentina in 2017.

\section{Argentina}

Forensic geology is rapidly increasing in importance worldwide for its contribution to clarify issues of both a criminal and humanitarian nature. Specifically, since the information provided substantially increases the chances of 
findings, the participation of geologists is considered crucial in searching for clandestine graves (Sagripanti et al., 2013). In this regard, over the last decade forensic geology has advanced significantly in Argentina with the aim of finding missing and forcibly disappeared persons.

Between 1976 and 1983, the Argentine Republic was ruled by a de facto government called "Military Dictatorship", a dark period in which thousands of people were arrested and forcibly disappeared. As part of this policy of enforced disappearance, this regime installed clandestine detention centres throughout the country, where victims of illegal arrests were systematically tortured, murdered, and made to disappear (CONADEP, 2006). The bodies were disposed in either single or mass graves, which were later concealed by different means such as vegetation, buildings or other structures, and cement slabs (Sagripanti et al., 2013).

The activities of forensic scientists, such as geneticists and anthropologists among others, have been fundamental to the recovery of the identity of missing persons. Their work begun when the word "disappeared" was used for the first time in Argentina during the above mentioned military dictatorship. However, the work of restitution of identity has not been exclusive of these forensic specialists, since geologists joined in the search more than a decade ago, with the creation of the Forensic Geology Team, pioneer in Argentina.

In 2004, geologists of the National Universities of Rio Cuarto and San Luis, on their own initiative, began carrying out activities as forensic geologists in the search for clandestine detention centres supporting Human Rights organizations, the Argentine Forensic Anthropology Team, families of missing persons, and law enforcement agencies in the search of forcibly disappeared persons both during the military dictatorship and the democracy.

These forensic activities, added to a protocol of various forensic investigators to have the support of geologists for locating clandestine graves, are the basis on which the Forensic Geology Team (EGF for its Spanish acronym) was formed. The techniques and tools used in conventional subsurface geological investigations were adapted to carry out near-surface surveys for detecting and delimiting anomalies, in order to attain the degree of accuracy required in this kind of search.

The Forensic Geology Team developed a methodology for locating clandestine burial sites which comprises several stages in which different techniques are used: inventory and selection of testimonies, analysis of vertical and oblique aerial photos taken at low altitude, satellite images, morpho-lithological and land use analysis. Once a potential gravesite is found, the area is analysed by geo-mechanical and geophysical methods (electric tomography and ground penetrating radar) and, finally, excavations are carried out by means of a specific technique to prevent the loss or destruction of evidence.

Undoubtedly, forensic geology has achieved increasing importance in Argentina as reflected not only in the knowledge and expertise acquired by the EGF (interpretation of GPR 2D profiles and excavation techniques), but also by the acknowledgment of forensic investigators of the support provided by forensic geologists in their search for truth and justice.

\section{Brazil}

Forensic geology in Brazil is mainly developed by experts from the Federal Police of Brazil trained in geology and mining engineering. Currently, the Federal Police of Brazil has 38 geologists responsible for acting in all 27 federative units in the country, spread across the capital and major cities. In addition, other forensic experts in related scientific fields such as chemistry, biology, agronomy, forestry, pharmacy, medicine, dentistry and engineering, form multidisciplinary teams, according to the specifics of the case.

Forensic Geology in the Federal Police contribute to the public security for the preservation of public order and the safety of people and property and the interests of the Union, exercising marine police activities, airport and borders, suppression of drug trafficking, smuggling and embezzlement, and exercising exclusively the judicial police functions. In this context, forensic geology is an important tool used for compliance with specific requirements in different stages of criminal investigations. Due to the great territorial scale of Brazil, the interpretation of satellite images and aerial images to combat deforestation and illegal mining activities in the Amazon region and pathless areas of the country, as well as the extensive monitoring of the Brazilian coast searching for indicators and traces of environmental crimes, are priority activities. Fraud, smuggling, and violent deaths associated with
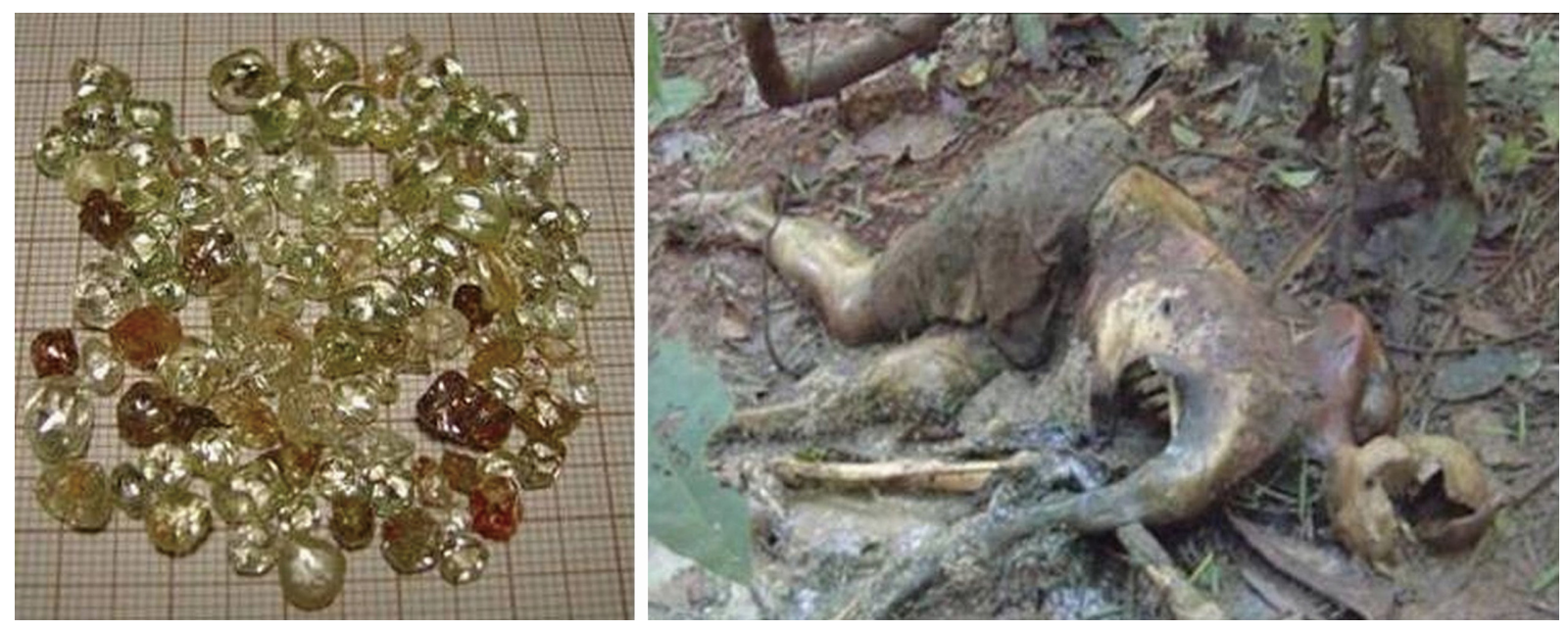

Figure 2. Forensic geologists provide support for the smuggling of diamonds and slaughter of miners in Rondônia, Brazilian Amazon (Photos: Fábio Salvador). 
extraction of gems and precious metals are important areas of investigation for forensic geologists, as well as actions combating the destruction of archaeological heritage and the irregular commercialization of minerals and fossils (Fig. 2).

\section{Colombia}

Geological knowledge applied to the forensic field in the Colombian judicial system began on $13^{\text {th }}$ December 1995 at the National Institute of Legal Medicine and Forensic Science. This resulted from an undergraduate thesis that began a year earlier, which included the validation of physical, chemical, and sedimentological methods for forensic soil analysis.

The Trace Evidence Laboratory has examined around 270 cases involving crimes such as homicide, robbery, embezzlement, fraud, kidnapping, personal injury, domestic violence, sex abuse, and violation of human rights. To help guide or clarify these, it has carried out laboratory analysis of trace evidence consisting of soils, minerals, rocks, building materials and glass. In addition, the laboratory has supported the analysis of bones, teeth and bullets that have required geological investigation for anthropologists, dentists and ballistics experts. Likewise the laboratory has assisted in fieldwork, mainly in cases searching for missing people, and sporadic support for example during a natural disaster, which left more than 100 victims.

The interaction between different disciplines is important in the forensic field; hence, in parallel, research by undergraduate and postgraduate thesis students has been developing not only within geology but also chemistry, law, dentistry and bacteriology. The most recent work was at the doctoral level, and was focused on the experimental application of geophysics in the search for missing people in the tropics (Fig. 3).

Currently, there is a need to apply the results of research to police case work, and to carry out further experimentation using forensic field laboratories to help locate multiple and individual grave on land

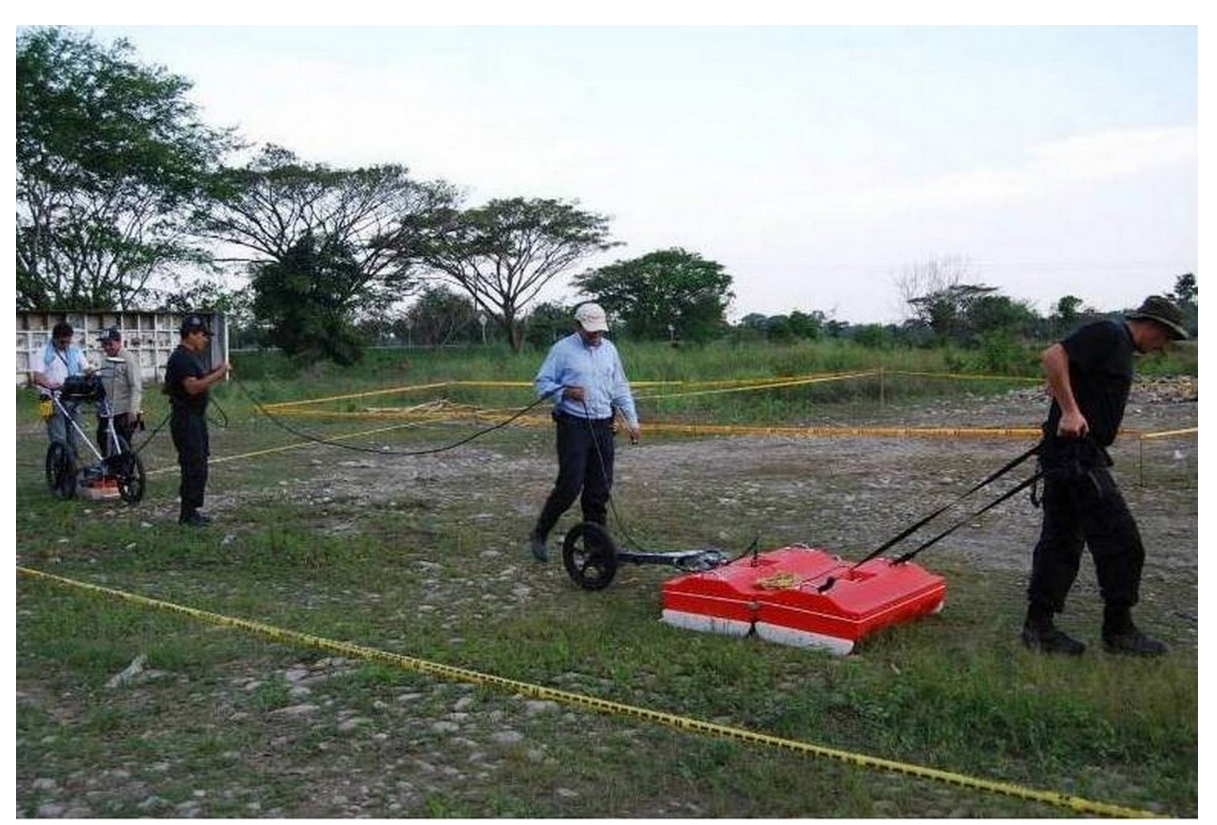

Figure 3. Searching missing people, human rights violation crime, in Colombia (Photo: Carlos Molina). and in water. Many of the estimated 80, 000 missing people were allegedly tortured, murdered and thrown into rivers, the search their remains requires a combination of different areas of expertise, including geology (Fig. 1).

\section{Mexico}

In Mexico, the State of Aguascalientes began to implement forensic geology. In particular, the 'General Direction of Expert Services of Aguascalientes' is in charge at crime scenes and performs laboratory analysis of materials collected from the crime scenes.

In 2010, the General Direction of Expert Services, pertaining to the Attorney General of the State Justice (Procuraduria General de Justicia del Estado, PGJE), in the person of its General Director Dr Aurelio Núñez Salas, introduced the training on forensic geology for 29 experts. This training, delivered by Carlos Martín Molina Gallego, (who later became one of the IUGS-IFG Officers for Latin America) was attended by professionals in the fields of medicine, chemistry, biology, law, engineering, psychology, and criminology.

The objectives of the training on forensic geology were to demonstrate and draw attention to the applications of geology in policing and law enforcement, including applications to the investigations of homicide, robbery, kidnapping, sex crimes, fraud, violation of human rights, terrorism and environmental damage. Specific goals were: (i) the applications of forensic geology to criminal investigations, (ii) the collection of geological materials from crime scenes and the chain of custody, (iii) the analytical methods in forensic geology, and (iv) the interpretation of geological results and the presentation of evidence in court. After this course, the experts have collected samples of soil during some judicial investigations considering those samples as important evidence in the investigation of the crime.

The National Autonomous University of Mexico has started scientific research on forensic geology for the Mexican and international judicial system. Specifically, the Institute of Geophysics, are developing the geophysical applications aimed at locating clandestine graves.

\section{Chile}

In 2016, a delegation from Chile visited the UK and Northern Ireland to discuss, "Disappeared but not forgotten: the Chilean experience regarding the search, recovery and identification of victims of human rights violations occurred during Pinochet's Dictatorship (1973-1990)". A series of meetings took pace in Belfast followed by a workshop, at Bradford, UK. Presentations were provided by the Medico-Legal Department, Government of Chile and a Professor of Transitional Justice at Ulster University's Transitional Justice Institute. UK archaeologists and forensic geologists representing IUGS-IFG took part in these discussions and provided advice on the search for graves. 


\section{Russia \& CIS}

In 1977, in Russia (the former Soviet Union), soil forensic examination became established in the Centre of Forensic Science of the Ministry of Justice. During the initial stages of examination, the fastest and cheapest methods are used, and then only if they are necessary or have potential significance to a case, more modern and expensive methods are applied. The main difference between Russian and non-Russian forensic geologists lies in the formulation of conclusions. This is due to the theory of forensic science, which has been developed by Russian jurists since the 1970s. Since that time all experts, working in different kinds of forensic disciplines, are required to formulate their conclusions in the same way according to this theory.

The bulk of soil forensic examinations in Russia deals with serious offences. Case work might include the investigation of illegal digging on territories of cultural and historical importance, land fraud, illegal excavation of building materials, substitution of expensive bulk cargos in containers by sand, fake building finishing materials, illegal dumping of municipal solid waste, amongst others.

If the objects under examination within related to an illegal excavation case includes digging tools, containing soil, the investigation comprises an standard comparative study. But, if the objects of investigation are artefacts taken from calcareous soils alternative sample analysis methods are required. For example, in a case comparing soil traces on cups from an ancient Greek excavation $\left(5^{\text {th }}\right.$ Century BC) in the cultural area of Krasnodar region (Taman), rich in calcareous soils, only the inner layers of the traces, hidden in deep holes and cracks of the artefacts, were used for examination.

In a case of land fraud in a Moscow region, a group of high-ranking officials were charged with the illegal acquisitions of plots of land. The defendants argued that they bought the plots three years before from a failed construction company, which had not completed the building, and built only the foundations. Freshly excavated trenches were found at these plots. The vegetation was also examined and the conditions of the soil covering the presence of any disturbance was investigated. It was subsequently found by the investigators that the construction works had not taken place.

Another example related to the transit of bulk cargos in containers through Dagestan. It was detected that the bulk cargos had been substituted partly by bags filled with sand and gravel. Detailed petrographic examination was conducted to find the provenance of the soil and gravel, which facilitated the investigation.

A case of illegal excavation of building materials, geological-mineralogical examinations were conducted to confirm that sandy soil, which was used for road construction had originated from an illegally excavated pit.

In another case, the examination of two visually identical marble slabs showed that one of them was made of high quality marble and the other was of a very low quality material with harmful impurities of micro size iron containing minerals.

\section{USA}

The title, Father of Forensic Geology in the $20^{\text {th }}$ Century, can be credited to Dr Raymond C. Murray with his seminal book, Forensic Geology-Earth Sciences and Criminal Investigation, first published with John C.F. Tedrow in 1975. Murray and Tedrow were the first to publish on this topic and raised the visibility of the science and were influential in eliminating the use of the density gradient column as an examination tool. Murray was assigned to IUGS-IFG as Honorary Committee member. He has since published a general audience book now in its second edition, Evidence from the Earth. Recently, many American Universities have begun offering courses in Forensic Geology. These courses are commonly at the introductory level. Dr Elisa Bergslien published in 2012 an excellent text book to meet the needs of her course and that of others titled: An Introduction to Forensic Geoscience.

In the United States, police organizations and thus crime laboratories are decentralized and exist in city, state and federal government facilities. Presently there are several laboratories in the United States performing advanced soil and mineral analysis. These include the Federal Bureau of Investigation (FBI), where several highly trained geologists perform analysis on soil, minerals, gemstones and glass. The forensic services of the FBI are available to all law enforcement agencies in the country. The Bureau of Alcohol Tobacco Firearms and Explosives, The Armed Forces Criminal Investigation Laboratory, and the Postal Inspection Service have employed forensic geologists. Several other contributors work in city, state, and private laboratories such as Microtrace and Microvision Northwest with expertise in chemistry and geological sciences. Some of the private laboratories play a very important role in the science in that they do studies both for defendants and law enforcement in the United States and in other countries. In addition, they work at the forefront of gathering evidence for civil litigation.

One of the earliest contributors to forensic soil analysis in the US was Edward Oscar Heinrich a professor of criminology at the University of California Berkley, who in 1921 and 1925 identified sand samples in connection with two high profile murders. In 1935 the FBI laboratory became one of the first forensic laboratories in the United States to use soil and mineral analysis in casework. In the early years Special Agents with geology specialties were employed. These agents were phased out and today the FBI employs several civilian experts with advanced degrees in geology performing soil, mineral, gemstone, and glass analysis. Currently the FBI mineralogy group is performing a great deal of research on provenance studies, pollen analysis, non-human DNA, cathodoluminance, isotopes, and Arc-GIS based mapping programs. In the past five years, the FBI has examined many materials from diamonds to concrete, garden gnomes and cases from weapons of mass destruction to insurance fraud. In many of the governmental and private laboratories there has been considerable recent work in the area of intelligence in addition to the regular work with criminal investigation.

A current renaissance in soil analysis and its implications in forensic science have ushered in the development of scientific working groups in the United States and abroad to advance and disseminate the application of sound scientific technical principles and research. In 2012, the Scientific Working Group for Geological Materials was established with participants from city, state, federal and private laboratories in the US. By 2014 this group was reorganized into a much more encompassing federal organization sponsored by the National Institute of Technology (NIST) known as the Organization of Scientific 
Area Committees (OSAC). This organization has a sub-group responsible for geological materials. The Geological Materials Subcommittee is focusing on standards and guidelines related to the collection, analysis, reporting, and interpretation of soils and other geological materials for forensic purposes.

There have been a few recent examples of governmental laboratories not adding or not replacing geologists for financial reasons or the need to meet the demand for DNA or drug examiners. This has resulted in an increased case load for the remaining FBI staff and private laboratories.

\section{References}

Al Naimi, K.S., 2015, Forensic archaeology: an introduction from the United Arab Emirates. in Mike Groen, W.J., Márquez-Grant, N., and Janaway, R.C. (eds.), Forensic archaeology: A global perspective: John Wiley \& Sons, Chichester, pp. 349-357.

Bergslien, E., 2012, An introduction to forensic geoscience: WileyBlackwell, Hoboken, $482 \mathrm{p}$.

Benninger, L.A., Carter, D.O., and Forbes, S.L., 2008, The biochemical alteration of soil beneath a decomposing carcass: Forensic Science International, v. 180 , no. 2-3, pp. 70-75.

CONADEP, 2006, Nunca Más. Informe de la Comisión Nacional sobre la Desaparición de Personas: 8va. Edición, 482 p., Ed. Eudeba.

Coney, L., Moila, A.V., and Quadling, A.G., 2012, Gem-quality diamonds: source discrimination: South African Journal of Geology, v. 115 , no. 1 , pp. 33-46.

Di Maggio, R.M., Barone, P.M., Pettinelli, E., Mattei, E., Lauro, S.E., and Banchelli, A., 2013, Geologia forense. Introduzione alle geoscienze applicate alle indagini giudiziarie: Dario Flaccovio, 320 p.

Dixon, R.D., Ueckermann, H., Espach, H.J., De Jager, L.L., and Roberts, R.J., 2007, Combatting the illegal gold trade using chemical profiling: Proceedings of the American Academy of Forensic Sciences, v. 13, pp. 44.

Donnelly, L.J., 2002, Finding the silent witness. The Geological Society of London, Geoscientist, v. 12, no. 5, pp. 16-17. (How forensic geology helps solve crime. All-Party Parliamentary Group for Earth Science. Westminster Palace, House of Commons, 12 March 2002)

Donnelly, L.J., 2008, Geoscientific equipment and techniques at crime scenes: $2^{\text {nd }}$ FGG Meeting of the Geological Society of London, Forensic Geoscience Group, Burlington House, London, December 17, pp. 36-38.

Donnelly, L.J., Cassella, J., Pirrie, D., Dawson, L., Harrault, L., Blom, G., Davidson, A., Arnold, P., Harrison, M., and Ruffell, A., 2016, Analysis of leachate, VOCs, fatty acids and mineralogy following the discovery of a homicide grave: Potential implications for police led open area ground searches for burials: $35^{\text {th }}$ International Geological Congress, Cape Town, August 29, T6.1 - Forensic Soil Science and Geology.

Donnelly, L.J., and Harrison, M., 2013, Geomorphological and geoforensic interpretation of maps, aerial imagery, conditions of diggability and the colour coded RAG prioritisation system in searches for criminal burials. in Pirrie, D., Ruffell, A.R., and Dawson, L. (eds.), Environmental and criminal geoforensics: Geological Society of London, Special Publication, 384, pp. 173-194.

Donnelly, L.J., and Harrison, M., 2015, A collaborative methodology for ground searches by a forensic geologist and law enforcement (police) officer: detecting evidence related to homicide, terrorism and organized crime: Proceedings of the $3^{\text {rd }}$ International Conference on Engineering Geophysics, Session on Forensic Geosciences, Al Ain, UAE, FG02, pp. 260-268.

Fitzpatrick, R.W., 2008, Nature, distribution and origin of soil materials in the forensic comparison of soils. in Tibbett, M., and Carter, D.O. (eds.), Soil analysis in forensic taphonomy: chemical and biological effects of buried human remains: CRC Press, Boca Raton, pp. 1-28.

Fitzpatrick, R.W., 2013a, Soils. in Siegel, J.A., and Saukko, P.J. (eds.), Encyclopedia of forensic sciences ( $2^{\text {nd }}$ edition): Academic Press, Waltham, USA. pp. 206-212. http://dx.doi.org/10.1016/B978-0-12-3821652.00113-6

Fitzpatrick, R.W., 2013b, Soil: forensic analysis. in Jamieson, A., and Moenssens, A., (eds.), Wiley Encyclopedia of Forensic Science: John Wiley \& Sons, Ltd., The Atrium, Southern Gate, Chichester, West Sussex, PO19 8SQ. http://dx.doi.org/10.1002/9780470061589.fsa096. pub2 (August 2013 updated articles)

Fitzpatrick, R.W., 2015a, A practical guide for recognition of soils with potential to cause faults in optical fibre cables (version 3): Acid Sulfate Soils Centre, Report ASSC_055., 40 p.

Fitzpatrick, R.W., 2015b, Analyses of four questioned soil samples on a pyjama top and fourteen control samples from the Onkaparinga river region relating to the Louis Bell investigation by SAPOL: Centre for Australian Forensic Soil Science, Restricted Client Report No. CAFSS 138, September 4, $116 \mathrm{p}$.

Fitzpatrick, R.W., and Raven, M.D., 2016, Guidelines for conducting criminal and environmental soil forensic investigations (version 10.1): Centre for Australian Forensic Soil Science, Report CAFSS_076, 46 p. http://www.adelaide.edu.au/directory/robert.fitzpatrick?dsn=directory.file; field=data;id=35757; $\mathrm{m}=$ view (accessed 11 February, 2016).

Fitzpatrick, R.W., and Raven, M.D., 2012, How pedology and mineralogy helped solve a double murder case: using forensics to inspire future generations of soil scientists: Soil Horizons, v. 53, no. 5, pp. 14-29.

Fitzpatrick, R.W., Raven, M.D., and Forrester, S.T., 2009, A systematic approach to soil forensics: criminal case studies involving transference from crime scene to forensic evidenc. in Ritz, K., Dawson L., and Miller, D. (eds.), Criminal and environmental soil forensics: Springer Science + Business Media B.V., pp. 105-127.

Forbes, S.L., Stuart, B.H., and Dent, B.B., 2005, The effect of the burial environment on adipocere formation: Forensic Science International, v. 154 , no. 1 , pp. 24-34.

Forensic Asia, 2009-2016, Newsletters: The Asian Forensic Sciences Network.

Gradusova, O., and Nesterina, E., 2009, The current status of forensic soil examination in the Russian Federation. in Ritz, K. et al. (eds.), Criminal and environmental soil forensics: Springer Science + Business Media B.V., pp. 61-73.

Gradusova, O., and Nesterina, E., 2016, Methodology of forensic soil examination in Russia and a view on the world standardization process. in Kars, H., and van den Ejkel, L. (eds.), Soil in criminal and environmental forensics: Proceedings of the Soil Forensics Special, $6^{\text {th }}$ European Academy of Forensic Science Conference, The Hague Springer International Publishing, pp. 121-136.

Marumo, Y., Nagatsuka, S., and Oba, Y., 1988, Rapid clay mineralogical analysis for forensic science investigation - Clay mineralogy over the short distances: Journal of Forensic Sciences, v. 33, no. 6, pp. 1360-1368.

McKinley, J.M., 2013, How useful are databases in environmental and criminal forensics? Geological Society of London, Special Publication, v. 384, no. 1, pp. 109-119.

McKinley, J.M., Ruffell, A., Harrison, M., Meier-Augenstein, W., Kemp, H., Graham, C., and Barry, L., 2009, Spatial thinking in search methodology: a case study of the 'No Body Murder Enquiry', West of Ireland. in Ritz, K., Dawson, L., and Miller, D. (eds.), Criminal and environmental soil forensics: Springer, pp. 285-302.

Molina, C.M., 2008, Historia y Desarrollo de la Geología Forense en Colombia: Revista Innovación y Ciencia, Asociación Colombiana para el Avance de la Ciencia, v. XV, no. 4, pp. 70-77.

Molina, C.M., Pringle, J., Saumett, M., and Evans, G.T., 2016, Geophysical monitoring of simulated graves with resistivity, magnetic susceptibility, conductivity and GPR in Colombia, South America: Forensic Science International, v. 261, pp. 106-115. 
Murray, R., and Tedrow J., 1975, Forensic geology: Rutgers University Press, New Brunswick, $211 \mathrm{p}$.

Murray, R., 2011, Evidence from the Earth ( $2^{\text {nd }}$ edition): Mountain Press, Missoulam, $201 \mathrm{p}$.

Murray, K.R., Fitzpatrick, R.W., Bottrill, R.S., Berry, R., and Kobus, H., 2015, Soil transference patterns on bras: Image processing and laboratory dragging experiments: Forensic Science International, v. 258, pp. 88-100.

Perelygin, A., Kuchkin, A., Kharkov, N., and Moskvina, T., 2008, Criminalistic identification of PGM-containing products of mining and metallurgical companies: Forensic Science International, v. 174, no. 1, pp. $12-15$.

Pirrie, D., Ruffell, A., and Dawson, L.A., 2013, Environmental and criminal geoforensics: Geological Society of London, Special Publication, v. 384 , no. 1,273 p.

Pye, K., and Croft, D.J., 2004, Forensic geoscience: principles, techniques and applications: Geological Society of London, Special Publication, v. $232,318 \mathrm{p}$.

Raven, M., Fitzpatrick, R.W., and Self, P.G., 2011, Forensic examination of small red brick fragments by laboratory source and synchrotron XRD techniques: Proceedings of Australian X-ray Analytical Association 2011 Workshops, Conference, and Exhibition (AXAA 2011), Abstract of Poster paper, February 6-11, Sydney, Abstract No. PP036.

Rikagaku-ka (Physics and Chemistry Section), 1950, Dosha kensa nitsuitenokentoh-kai (Report of discussion on forensic soil examination): Kagaku to Sousa (Science and Detection), Japan, v. 3, no. 2, pp. $115-122$.

Ritz, K., Dawson A.L., and Miller, D., 2009, Criminal and environmental soil forensics: Springer, $519 \mathrm{p}$.

Roberts, R.J., Dixon, R.D., and Merkle, R.K., 2016, Distinguishing between legally and illegally produced gold in South Africa: Journal of Forensic Sciences, v. 61, Suppl. 1, pp. S230-S236.

Sagripanti, G., Villalba, D., Aguilera, D., and Giaccardi, A., 2013, Geología Forense: Métodos aplicados en la búsqueda de desaparecidos en la región central de Argentina: Revista de la Asociación Geológica Argentina, v. 70, no. 1, pp. 150-160.

Sugita, R., and Marumo, Y., 1996, Validity of color examination for forensic soil identification: Forensic Science International, v. 83, no. 3, pp. 201-210.

White, D., 2005, Curse of Africa's precious metal haunts miners: Financial Times. http://on.ft.com/2rV3o5J

Young, J.M., Weyrich, L.S., Clarke, L.J., and Cooper, A., 2015, Residual soil DNA extraction increases the discriminatory power between samples: Forensic Science, Medicine and Pathology, v. 11, no. 2, pp. 268272.

Young, J.M., Weyrich, L.S., Clarke, L.J., and Cooper, A., 2016, Highthroughput sequencing of trace quantities of soil provides reproducible and discriminative fungal DNA profiles: Journal of Forensic Sciences, v. 61, n. 2, pp. 478-484.

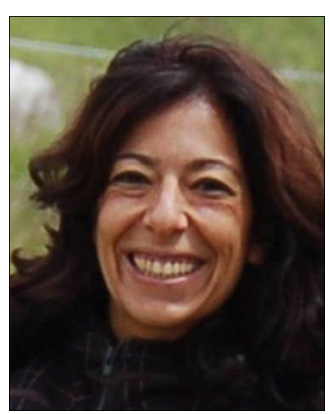

Rosa Maria Di Maggio has a MESc cum laude in Geological Science and has more than fifteen years of experience in forensic geology, ten of them spent at the Italian Forensic Science Police Department. She carried out more than 80 criminal cases with reference to analysis of soil and inorganic materials. Rosa Maria has published several scientific publications and she is the co-author and the editor of the first Italian book on forensic geology.

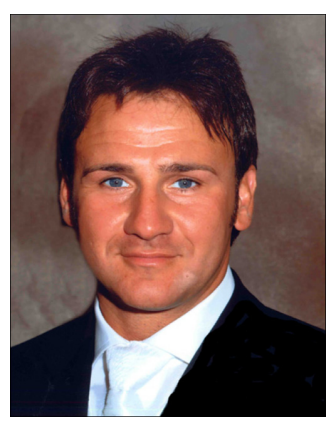

Laurance Donnelly is a professional, chartered, geologist with a first class honours degree (BSc) in Applied Geology and Ph.D. in Geohazards. He has 27 years of international experiences in: mineral exploration, mining geology, engineering geology, geohazards and forensic geology. He has pioneered new ground search strategies for graves and other burials related to homicide, serious organised crime and terrorism. He has also advised the police on cases involving geological trace evidence. He is registered as an Expert Adviser with the UK National Crime Agency. He is the founder of the IUGS Initiative on Forensic Geology and Geological Society of London, Forensic Geoscience Group.

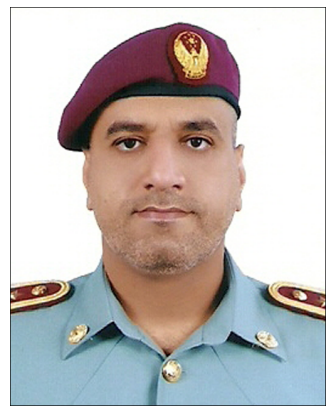

Khudooma Saeed AL Nuaimi holds BSc, MSc, MBA. He is working in the Forensic Biology Section, Department of Forensic Evidences in the Abu Dhabi Police GHQ, Ministry of Interior, United Arab Emirates since 2000 . His duties include attending crime scene investigation, laboratory examination of evidences, writing reports, and training new staff. His research interest includes forensic anthropology, forensic archaeology, forensic biology, forensic entomology, and trace evidences. He is a member of the American Academy of Forensic Sciences, the International Association of Identification, and the International Academy of Legal Medicine. He volunteered in 2005 with the ICMP in the identification of war victims in Bosnia and Herzegovina. He published two chapters in two books in 2009 and 2016. 